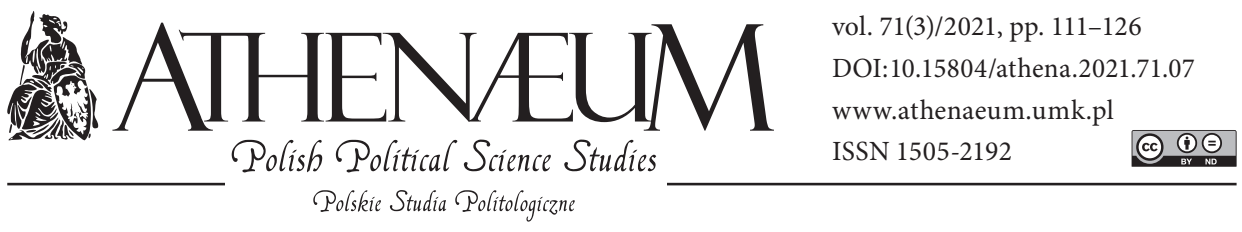

\title{
EXTENDED PRODUCER RESPONSIBILITY AS A PILLAR OF CIRCULAR ECONOMY: CURRENT CHALLENGES FOR POLISH WASTE MANAGEMENT POLICY AND LAW
}

\author{
ROZSZERZONA ODPOWIEDZIALNOŚĆ PRODUCENTA \\ JAKO FILAR GOSPODARKI OBIEGU ZAMKNIĘTEGO - \\ AKTUALNE WYZWANIA DLA POLSKIEJ POLITYKI I PRAWA \\ W ZAKRESIE GOSPODAROWANIA ODPADAMI
}

Karolina Karpus* (1)

\begin{abstract}
Od 3 lat nowe kierunki unijnej polityki i prawa ochrony środowiska w zakresie odpadów wyznaczają cele ujęte w dokumencie Unii Europejskiej z 2018 roku dotyczącym gospodarki o obiegu zamkniętym. Odnoszą się one w złożony sposób do jednego z filarów gospodarki o obiegu zamkniętym, jakim jest rozszerzona odpowiedzialność producenta (ROP). Ustawodawca polski rozpoczął wstępne działania dotyczące wykorzystania ROP w sposób odpowiadający nowym celom gospodarowania odpadami (np. marnowanie żywności). Aktualnie najbardziej problematycznym obszarem wymagającym zmiany jest gospodarowanie odpadami komunalnymi. Szczególnie pilnym wyzwaniem jest skoordynowanie istniejących w Polsce schematów ROP z gminnym systemem gospodarowania odpadami komunalnymi.
\end{abstract}

The objectives included in the EU 2018 Circular Economy Package have been determining the new directions of the EU environmental policy and law for three years now. They refer in a complex way to one of the Circular Economy pillars, i.e., Extended Producer Responsibility (EPR). The Polish legislator has undertaken initial actions concerning the use of EPR in a way corresponding to the new objectives of waste management (e.g., food waste). Currently, the most problematic area requiring changes is municipal waste management. The most urgent issue is the coordination of already existing in Poland EPR schemes with gmina's municipal waste management systems.

\footnotetext{
* Nicolaus Copernicus University in Toruń, Faculty of Law and Administration.
} 
Słowa kluczowe: rozszerzona odpowiedzialność producenta (ROP); gospodarka o obiegu zamkniętym (GOZ); prawo o odpadach; odpady komunalne
Keywords: Extended Producer Responsibility (EPR); Circular Economy (CE); waste law; municipal waste

\section{INTRODUCTION}

Circular Economy as a social-economic concept, consistent with the objectives of sustainable development principle, has been infiltrating the EU law and policy for over a decade. The process is apparent in environmental law and the Circular Economy (CE) objectives are particularly important for waste law. If the implementation of the CE objectives succeeds, the approach to the environmental emission, which is waste, will significantly change. However, to achieve such a state of affairs, it is necessary to use varied environmental law and policy instruments.

The application of such an instrument in practice is usually connected with the need to overcome several entry barriers of different nature: social, economic, technical, organizational or finally legal ones. Extended producer responsibility (EPR) is the example of an instrument which combines these challenges. The implementation of EPR in Poland is taking place mainly and above all due to the influence of EU law, since the Polish legislator has not shown much ambition of independent development of EPR so far, aside from the areas required by EU law.

Undoubtedly, CE is an environmental law objective of the Polish State, however, there are still difficulties in adopting appropriate legal and organizational solutions leading to its implementation. The audit conducted by the Supreme Audit Office in 2020 confirmed it. Evaluating the solutions concerning plastic waste management - in a broader context of municipal waste management in Poland - the Supreme Audit Office expressed its doubts as to whether public authorities in Poland are capable of implementing radical solutions "leading to an essential change within the matter, although the necessity to improve the efficiency of using material resources and to increase the rate of plastic waste recycling results from the CE guidelines" (NIK, 2021, p. 16).

Meanwhile, the EU policy concerning CE has accelerated recently. It results not only from the newly adopted objectives within the European Green Deal (EGD), but also from the works on the implementation of the $8^{\text {th }}$ Environmental Action Programme for the years 2021-2030. As a result of these actions, the 
ambitions of the EU CE are growing, which evidently must have an influence on the environmental policy and law of each EU Member State. A significant example is the implementation of EU charge on non-recycled plastic waste paid by Member States within the EU resources system since 2021 (EC, 2020a, pp. 9,65 ), calculated at $€ 800$ per tonne (Victory, 2020). All things considered, the reorganization of waste management is crucial both for environmental protection in Poland and for the financial affairs of the Polish State.

\section{THE EU CIRCULAR ECONOMY AND EU WASTE LAW}

It is indicated that the concept of CE has been developing since the $1970^{\mathrm{s}}$ as an alternative model of economic development in comparison to a traditional model, defined as linear economy (Taranic, Behrens, \& Topi, 2016, p. 2). Currently, $\mathrm{CE}$ is usually described, as the economy based on the "reduce-reuse-recycle" model being the opposite of the linear "take-make-dispose" economy (Jørgensen \& Pedersen, 2018, pp. 105-106). In the context of waste, a particularly important aspect of CE is the notion of "decoupling". According to the UNEP systematics, it is divided into two categories: "resource decoupling" and "impact decoupling". According to the definition, "resource decoupling" means "reducing the rate of use of (primary) resources per unit of economic activity. This 'dematerialization' is based on using less material, energy, water and land resources for the same economic output. Resource decoupling leads to an increase in the efficiency with which resources are used”. Whereas "impact decoupling”: “[...] requires increasing economic output while reducing negative environmental impacts, including impacts arising from production (such as land degradation, wastes and emissions) and in the post-consumption phase (again wastes and emissions)" (UNEP, 2011, p. 4).

Currently, it is difficult to indicate an independent legal definition of "Circular Economy" adopted in the EU or Polish law. However, one can make use of definitions adopted in EU documents or in a given Member State. Two of them seem to be especially useful. In the taxonomy used by Eurostat it is indicated that "circular economy aims to maintain the value of products, materials and resources for as long as possible by returning them into the product cycle at the end of their use, while minimising the generation of waste" (Eurostat, n.d.). Whereas, in Poland's Road Map towards the Transition to Circular Economy it was indicated that $\mathrm{CE}$ "is an economic development model in which the follow- 
ing basic assumptions are met while maintaining the productivity condition: a) added value of raw materials/resources, materials and products is maximised or b) amount of waste generated is minimised and the resulting waste is managed in accordance with waste hierarchy (waste prevention, preparation for re-use, recycling, other recovery, disposal)" (RM, 2019, p. 5).

The concept of CE is a subject of analyses both at the level of international and the EU cooperation. In the UN forum, admittedly in Agenda 2030 (UN, 2015), it is not directly defined as an independent Sustainable Development Goal (SDG), however, there are some links between the concept and at least several of 17 SDGs and their targets. The assessment of those links leads to the conclusion that the $\mathrm{CE}$ business models and strategies "[...] directly contribute to achieving 21 of the targets and indirectly contribute to an additional 28 targets. The strongest relationships exist between CE practices and targets of SDG 6 (Clean Water and Sanitation), SDG 7 (Affordable and Clean Energy), SDG 8 (Decent Work and Economic Growth), SDG 12 (Responsible Consumption and Production), and SDG15 (Life on Land)" (Schroeder, Anggraeni, \& Weber, 2019, p. 92).

Within the EU policy, the concept of CE is a subject of definitely more thorough analyses and solutions than at the level of $U N$ as yet. It arises as an objective of EU policy and law both in general documents (the EGD), in environmental law documents (the $7^{\text {th }}$ EAP, the $8^{\text {th }}$ EAP) and finally as an issue analysed in documents and acts devoted, above all, to waste management. For example, the European Commission describes the solutions encompassed within the EGD as "a new growth strategy that aims to transform the EU into a fair and prosperous society, with a modern, resource-efficient and competitive economy where there are no net emissions of greenhouse gases in 2050 and where economic growth is decoupled from resource use" (EC, 2019, p. 2). Article 1(2) of the new EU EAP draft also stresses that "the $8^{\text {th }}$ EAP aims at accelerating the transition to a climate-neutral, resource-efficient, clean and circular economy in a just and inclusive way, and endorses the environmental and climate objectives of the European Green Deal and its initiatives" (EC, 2020b). And according to Art. 2(2) (c) one of the six priority objectives of the $8^{\text {th }}$ EAP for the years 2021-2030 is also "advancing towards a regenerative growth model that gives back to the planet more than it takes, decoupling economic growth from resource use and environmental degradation, and accelerating the transition to a circular economy".

As it was pointed above, the objective called "decoupling" within CE has a significant meaning for waste management, which as a consequence has its reflection in new legal solutions proposed at the level of EU waste law. The frames of 
waste policy, within which such legal measures are adopted by the EU legislator, have been formulated in several legal documents (e.g., EC, 2011; EC, 2014) for more than a decade. Moreover, two CE Action Plans (EC, 2015; EC, 2020) have already been adopted at the EU level. The First EU CE Action Plan concerned actions in three main areas: production, consumption, and waste management. In the New Circular Economy Action Plan waste management (part. 4: "Less Waste, More Value") is also a central problem next to such key actions like: "Sustainable Product Policy Framework" and "Key Product Value Chains". As one of the main measures within the First EU CE Action Plan, "revised legislative proposal on waste" was provided. Within it, in 2018, as a part of so-called EU Circular Economy Package, the directives amending the EU waste law (Karpus, 2018) were adopted. Several legislative proposals are also to be expected within the implementation of the New 2020 EC Action Plan objectives, e.g., on account of establishing a new "right to repair".

A legal instrument, to which the EU legislator paid a lot of attention within the 2018 EU Circular Economy Package is Extended Producer Responsibility (EPR). This instrument has been present in the EU waste law for a long time, however, in the light of the $\mathrm{CE}$ objectives has undoubtedly required reorganization and development.

\section{EPR DE LEGE LATA IN EU AND POLISH WASTE LAW}

Extended Producer Responsibility is undoubtedly one of the pillars of Circular Economy (Ogunmakinde, Sher, \& Egbelakin, 2021, p. 908). One of the bestknown extra-legal definitions of this notion was proposed by T. Lindhqvist, according to whom EPR is "environmental protection strategy to reach an environmental objective of a decreased total environmental impact from a product, by making the manufacturer of the product responsible for the entire life-cycle of the product and especially for the take-back, recycling and final disposal of the product" (Lindhqvist, 2000, p. 9). The EPR concept has been successively infiltrating EU policy and law for the last two decades. It is especially significant in the EU waste law for the management of chosen streams of waste, e.g., packaging waste or waste of electrical and electronic equipment (WEEE).

In the concept proposed by T. Lindhqvist, EPR as a strategy embraces four kinds of producer's responsibilities for a product, which afterwards becomes waste, i.e., legal, economic, physical and informative responsibilities (Lindhqvist, 
2000). By transferring this division of responsibilities to the legal area, the question may be interpreted by enumerating legal responsibilities resulting from EPR. Thus, it can be assumed that EPR as a legal institution may embrace the following groups of legal responsibilities: 1) responsibilities resulting from systematic solutions implementing integrated product policy within Circular Economy, based on "product life-cycle": a) responsibilities introduced at the stage of product initial usability (design, production, marketing); b) responsibilities introduced at the stage of waste management (collection, recycling, disposal, end-of-waste status); 2) responsibilities related to levies, taxes and charges, imposed within systematic solutions implementing integrated product policy; 3) responsibilities arising from legal responsibility for: a) breach of legal responsibilities resulting from systematic solutions implementing integrated product policy (sanctions); b) causing harm to environment (liability) (Karpus, 2014, pp. 247-248).

The EU legislator had been using EPR regulating legal obligations in chosen waste for a long time, however, EPR was explicitly encompassed in the Waste Framework Directive as an instrument of EU law on waste only in 2008 (OJ, 2008). Article 8(1) of Directive 2008/98/EC indicates that: "In order to strengthen the re-use and the prevention, recycling and other recovery of waste, Member States may take legislative or non-legislative measures to ensure that any natural or legal person who professionally develops, manufactures, processes, treats, sells or imports products (producer of the product) has extended producer responsibility. Such measures may include an acceptance of returned products and of the waste that remains after those products have been used, as well as the subsequent management of the waste and financial responsibility for such activities. These measures may include the obligation to provide publicly available information as to the extent to which the product is re-usable and recyclable". At the same time, as it results from Art. 8(4), EPR "shall be applied without prejudice to the responsibility for waste management as provided for in Article 15(1) and without prejudice to existing waste stream specific and product specific legislation".

The analysis of Art. 8(1) and (4) of Directive 2008/98/EC leads to the conclusion that EPR as a compulsory legal instrument is currently applied only in chosen streams of waste, for which the EU legislator adopted "waste stream specific legislation" (e.g., packaging waste, WEEE, waste batteries and accumulators, end-of-life vehicles). Beside these streams of waste, the legislator of a given Member State still retains the right to an independent decision to, whether and to which extent, implement EPR in their national law on waste. In other words, 
in this context EPR is only an optional legal instrument possible to be used in waste law of a given Member State (Karpus, 2014, pp. 250-251).

The revision of Directive 2008/98/EC (by Directive (EU) 2018/851 - being an element of the 2018 EU CE Package) did not change this state of affairs (OJ, 2018). Still each Member State has liberty of decision regarding the use of EPR in their national waste law in matters not regulated by EU specific waste stream legislation. The emphasis in Directive (EU) 2018/851 was put on the fact that the legislator of a given Member State, who actually applies EPR, should impose legal obligations within that instrument in a form unified at the EU level. Therefore, according to Art. 8(1) Directive 2008/98/EC in its new version, a Member State is obliged to consider in this scope so-called general minimum requirements for EPR schemes encompassed in new Art. 8a.

According to Art. 8a(1) of Directive 2008/98/EC, "where extended producer responsibility schemes are established in accordance with Article 8(1), including pursuant to other legislative acts of the Union, Member States shall: (a) define in a clear way the roles and responsibilities of all relevant actors involved, including producers of products placing products on the market of the Member State, organisations implementing EPR obligations on their behalf, private or public waste operators, local authorities and, where appropriate, re-use and preparing for re-use operators and social economy enterprises; (b) in line with the waste hierarchy, set waste management targets, aiming to attain at least the quantitative targets relevant for the EPR scheme as laid down in this Directive, Directive 94/62/EC, Directive 2000/53/EC, Directive 2006/66/EC and Directive 2012/19/ EU of the European Parliament and of the Council, and set other quantitative targets and/or qualitative objectives that are considered relevant for the EPR scheme; (c) ensure that a reporting system is in place to gather data on the products placed on the market of the Member State by the producers of products subject to EPR and data on the collection and treatment of waste resulting from those products specifying, where appropriate, the waste material flows, as well as other data relevant for the purposes of point (b); (d) ensure equal treatment of producers of products regardless of their origin or size, without placing a disproportionate regulatory burden on producers, including small and medium-sized enterprises, of small quantities of products".

In reference to financial responsibility of producer of the product, Art. $8 \mathrm{a}(4)$ (a) of Directive 2008/98/EC implements an explicit requirement so that within a given national EPR scheme the producer will be at least obliged to cover the following costs for the products that the producer puts on the market in the 
Member State concerned, like: costs of separate collection of waste and its subsequent transport and treatment, including treatment necessary to meet the Union waste management targets, and costs necessary to meet other targets and objectives set in line with the waste hierarchy, taking into account the revenues from re-use, from sales of secondary raw material from its products and from unclaimed deposit fees; costs of providing adequate information to waste holders targeted by the given EPR scheme; and costs of data gathering and reporting on the products placed on the market of the Member State by the producers of products subject to EPR and on the collection and treatment of waste resulting from those products.

The Polish legislator implemented EPR schemes required by Directive 94/62/ EC, Directive 2000/53/EC, Directive 2006/66/EC and Directive 2012/19/EU in several acts (OJPL, 2001; OJPL, 2005; OJPL, 2009; OJPL, 2013; OJPL, 2015), which should be classified as national "waste stream specific legislation" acts.

While implementing solutions within the 2018 Circular Economy Package, the Polish legislator has so far decided to implement only one new EPR scheme by the Act of 19 July 2019 on counteracting food waste (OJPL, 2019; Sokołowski, 2019, pp. 172-180). The problem of "food waste" was defined in Article 2(1) of the act as "withdrawal of foods from the distribution stage, when such foods still meet the requirements of food law, in particular due to the approaching expiry of the use-by date or the date of minimum durability or due to defects in the appearance of these foodstuffs or their packaging, and their disposal as waste". Within this new EPR scheme the main obliged is the entity qualified as "food business operator". According to Art. 3(3) of the act, it is "a person operating a food business referred to in Art. 3 section 2 of the regulation (EC) No 178/2002 carrying out the activities of food distribution in retail or wholesale trade unit with the sales area [...] exceeding $250 \mathrm{~m}^{2}$, whose sales revenues from food constitute at least $50 \%$ of the revenues from all goods". According to Art. 17 of the Act, the years 2019-2021 are transitional period, during which only food operators, whose retail or wholesale trade unit has the sales area exceeding $400 \mathrm{~m}^{2}$, participate in EPR scheme.

The Act imposes on food operators within EPR scheme the following legal obligations:

- obligation to conclude an agreement with at least one authorized nongovernmental organization (NGO) regarding free of charge transfer of food fulfilling the requirements of food law and not intended for sale, in particular due to its appearance or packaging flaws (except for alcoholic beverages) (Art. 3); 
- obligation to conduct, at least once a year for two consecutive weeks, on each day of the unit's commercial activity in retail outlets together with an $\mathrm{NGO}$, educational and information campaigns on rational food management and counteracting food waste (Art. 4);

- obligation to pay fees for food waste (Art. 5);

- obligation to submit annually, by March 31, a written report to the voivodship fund for environmental protection and water management containing information on the total weight of food wasted in the previous year and the amount of fee due (Art. 8).

The new fee for food wasting is calculated as the product of the rate and the mass of wasted food at the end of the calendar year. The basis for calculating the fee is $90 \%$ of the mass of wasted food in kilograms and the fee rate is PLN 0,1 per $1 \mathrm{~kg}$ of wasted food. The food operator pays the fee by April 30 of the following calendar year to the bank account of the NGO that is a party of the concluded agreement and in the event of a failure to conclude an agreement to the bank account of the voivodship fund for environmental protection and water management. According to Art. 6(1) of the Act, the funds originating from the fee are to be used for financing the activities listed in the Act, i.e., social assistance, supporting the family and a system of substitute care; charity activities consisting in food transfer to people in need or in running mass caterer facilities for people in need; and for the activities aimed at combating food waste.

\section{MUNICIPAL WASTE MANAGEMENT IN POLAND AND EPR SCHEMES}

The implementation of new solutions regarding the mentioned above EPR scheme on waste food has been so far the only example of specific actions taken by the Polish legislator under the influence of the 2018 EU Circular Economy Package. Admittedly, during last two years another two successive government draft bills on EPR schemes (UC43, 2020; UC73, 2021) were made public but both are on the early stage of legislative procedure and have not been yet presented to Parliament.

Meanwhile, new Package objectives concerning chosen waste streams oblige the Polish legislator to assess critically the effectiveness of existing so far EPR schemes in Poland (implemented by the acts being a part of "waste stream specific legislation"). As indicated in Road Map, "it is necessary to define more clearly 
the roles and obligations of individual entities participating in the implementation of EPR, to impose obligations on entities other than producers, to set new objectives concerning preparation for reuse and recycling of individual waste flows, to develop a system for reporting on the implementation of EPR, and to ensure equal treatment of all entrepreneurs by the system. [...] It may turn out that it will also be necessary to analyse the role of individual market participants, including recovery organisations, and introduction of changes in the system financing" (RM, 2019).

Limiting ourselves only to two waste streams - WEEE and packaging waste - two sample challenges, which require an urgent reaction from the Polish legislator, may be indicated. In the case of EPR scheme on WEEE, one of the biggest problems in Poland is the system of financing the collection and recycling of WEEE. For years the main pathology, besides grey market, has been the difficulty in the correct regulation of height of service costs of WEEE collection and recycling (Pyssa, 2015). One of the suggested solutions, which could remedy the situation, is the proposal to establish a market regulator within WEEE in order to inhibit a rapid drop of prices for WEEE recycling services. Its main task would be to set, audit and approve minimal service prices for the collection and recycling of WEEE (Laskowska, 2018). A similar problem of incorrect relations between actual waste collection and recycling costs and expenses incurred in this respect by entities placing products on the market and recovery organizations is noticeable in the case of packaging waste (Styś \& Foks, 2016a, p. 35; Moskwik et al., 2020, p. 50). Among the suggested solutions regulating the management of such waste is the proposal of introducing deposit system, at least in the case of some packaging (Rudewicz, 2020, pp. 67-68). Meanwhile, in the case of both these waste streams it is indicated that there is no synergy between the systems of managing them and the system of municipal waste management (Styś \& Foks, 2016, p. 51; Moskwik et al., 2020, p. 56). The improvement in this scope is a sine qua non condition of achieving new objectives of municipal waste management, set in the 2018 EU Circular Economy Package, because most of municipal waste is covered by EPR schemes at the same time.

The so-called reform of municipal waste management has been successively introduced in Poland since the turn of 2011/2012 (OJPL, 1996). Within this reform, gminas were entrusted with the management of municipal waste and are obliged to collect and recycle it. Unfortunately, until now the legislative changes have contributed to the improvement of the cohesion between gmina system 
and existing EPR schemes only to a small extent. One of the few existing solutions is, for example, the gmina's obligation to run "selective collection points for municipal waste", which also collect WEEE.

The implementation of reform concerning municipal waste management in Poland is being far from the ideal. Only in July 2017, the regulation of the Minister of Environment implementing a nationally unified selective waste container labelling system entered into force (OJPL, 2016). The regulation, however, allows a five-year adjustment period, which means that unified solutions in this scope will be fully implemented in all gminas only in 2022. Moreover, in the years 2013-2019, the Polish legislator gave inhabitants of gminas the choice as to the method of waste disposal to gmina's collection system, i.e., either selectively or as mixed waste. Depending on the choice, inhabitants paid lower or higher fees for municipal waste management to gmina. Only with another amendment in 2019 (with the transition period until December 31,2020), the possibility of disposing municipal waste not collected selectively into following fractions: paper, metal, plastic, glass, mixed packaging waste and bio-waste, was finally eliminated. Currently, non-compliance with the administrative order to collect such fractions of municipal waste selectively is subject to an administrative-financial sanction, i.e., a higher fee for municipal waste management. According to current Art. 6k(3) of the Act of 1996, its height is determined by the council of gmina between minimum twice and maximum four times the height of currently binding fee in a given gmina taking into account a regular fee.

For almost a decade of implementing the reform concerning municipal waste management, the Polish legislator has not made an effort to harmonize, to at least some extent, municipal waste management system with existing EPR schemes. The new objectives resulting from the 2018 EU Circular Economy Package have become an important impulse to perform analyses in this scope, although they have not produced measurable effects. In the period between September 2019 and January 2020, the Minister of Climate presented an initial proposal on changes concerning the coordination of systems with reference to packaging waste (MKPL, 2020).

The proposal of the Minister of Climate encompasses the following solutions:

- meeting statutory obligations by entities placing products in packaging on the market solely through packaging waste recovery organisations (now they can still do it independently);

- imposing fee to be paid to gmina on entities placing products in packaging for households; 
- establishing a system regulator (Ministry of Climate or entity designated by him), who would also embrace other EPR scheme, e.g., WEEE in the future;

- establishing a deposit system, run by recovery organizations, for single-use or reusable packaging including at least plastic bottles up to 31 , aluminium cans up to 1 , glass bottles up to 1.51 .

The increased activity of the Minister, explicitly in the scope of the stream of packaging waste, might be explained by the pressure resulting from the Art. 7(2) of the amended Directive 94/62/EC, according to which Member States have to "ensure that, by December 31, 2024, extended producer responsibility schemes are established for all packaging in accordance with Articles 8 and $8^{\mathrm{a}}$ of Directive 2008/98/EC". Two above mentioned government draft bills on EPR schemes were published in 2020-2021, albeit both of them being only of a fragmentary nature. However, there is still no sign of any framework legislative initiative in that regard (ROP, 2020; Toborek, 2021).

\section{CONCLUSIONS}

There is no doubt that the EU legislator classifies the EPR instrument as one of the pillars of Circular Economy. The changes in EU waste law resulting from this fact urge national legislators of each Member State to carry out thorough analyses of the previous use of EPR schemes in national law. So far, the Polish legislator has only partially fulfilled this obligation resulting unambiguously from the EU 2018 Circular Economy Package.

Still, the main area which has not been sufficiently changed in Poland is municipal waste management. The Polish legislator has still not decided to implement vital legal solutions synchronizing gmina system with existing EPR schemes, introduced by "specific waste legislation" acts. Among those necessary amendments is the arrangement of organizational and financial principles, defining the obligations of public authority bodies (gminas) and the obligations of producers of products and recovery organizations. The other, very important, area of amendments in this scope are the obligations and rights of a consumer, being the holder of municipal waste. So far, the lack of cohesion results in the fact that consumers receive confusing information about their obligation and rights towards gmina and producers of products. As a result, such information chaos does not favour consumers' habits to more environmentally friendly. Therefore, 
the transformation towards CE in Poland in this scope is not going fast and efficiently enough, especially within municipal waste management.

Currently in Poland there is a situation of classic "cognitive dissonance". On the one hand, it seems that "decoupling" as a desirable direction of changes in the economy is already taking place. As the Statistics Poland assesses, “[...] the growth rate of generating municipal waste has been lower than the growth rate of consumption in the households sector. In 2019, it was respectively at $36,4 \%$ and $63,1 \%$, which shows a relative decoupling between the amount of generated municipal waste and consumption in a household sector" (GUS, 2020a, p. 25). However, in 2019, still $44 \%$ of that waste went to disposal (1\% to incineration, $43 \%$ to landfills) (GUS, 2020, p. 158) and thereby lost as possible secondary resource. Among the methods of changing this relation in the future, which should be applied by the Polish legislator as soon as possible, is the coordination of EPR schemes with gmina systems.

\section{REFERENCES:}

EC (2011). Communication from the Commission to the European Parliament, the Council, the European Economic and Social Committee and the Committee of the Regions: "Roadmap to a Resource Efficient Europe", $\operatorname{COM(2011)571~final.~Retrieved~}$ from: https://eur-lex.europa.eu.

EC (2014). Communication from the Commission to the European Parliament, the Council, the European Economic and Social Committee and the Committee of the Regions: "Towards a Circular Economy: A Zero Waste Programme for Europe", COM/2014/0398 final. Retrieved from: https://eur-lex.europa.eu.

EC (2015). Communication from the Commission to the European Parliament, the Council, the European Economic and Social Committee and the Committee of the Regions: "Closing the Loop - An EU Action Plan for the Circular Economy", COM/2015/0614 final. Retrieved from: https://eur-lex.europa.eu.

EC (2019). Communication from the Commission: "The European Green Deal", $\operatorname{COM}(2019) 640$ final. Retrieved from: https://eur-lex.europa.eu.

EC (2020). Communication from the Commission to the European Parliament, the Council, the European Economic and Social Committee and the Committee of the Regions: "A New Circular Economy Action Plan - For a Cleaner and More Competitive Europe", $\operatorname{COM(2020)} 98$ final. Retrieved from: https://eur-lex.europa. eu.

EC (2020a). Special Meeting of the European Council (17, 18, 19, 20 and 21 July 2020) - Conclusions. Retrieved from: https://www.consilium.europa.eu/ media/45109/210720-euco-final-conclusions-en.pdf. 
EC (2020b). Proposal for a Decision of the European Parliament and of the Council on a General Union Environment Action Programme to 2030, COM(2020) 652 final - 2020/0300 (COD). Retrieved from: https://eur-lex.europa.eu.

Eurostat (n.d.). Circular Economy - Overview. Retrieved from: https://ec.europa.eu/ eurostat/web/circular-economy.

GUS (2020). Environment 2020. Warsaw: Statistics Poland.

GUS (2020a). Wskaźniki zielonej gospodarki w Polsce 2020. Warszawa-Białystok: GUS. Jørgensen, S., \& Pedersen, L.J.T. (2018). RESTART Sustainable Business Model Innovation. London-Cham: Palgrave Macmillan, Springer.

Karpus, K. (2014). „Rozszerzona odpowiedzialność producenta” jako instytucja prawa o odpadach. In: B. Rakoczy, M. Szalewska, \& K. Karpus (Eds.). Prawne aspekty gospodarowania zasobami środowiska. Oddziaływanie na zasoby środowiska (pp. 239-252). Toruń: Towarzystwo Naukowe Organizacji i Kierownictwa Dom Organizatora.

Karpus, K. (2018). New Developments of the EU Circular Economy Policy and Their Impact on EU Waste Law. Athenaeum. Polish Political Science Studies, 60, 97-113. DOI: 10.15804/athena.2018.60.06.

Laskowska, M. (2018). ZSEE dwa lata po nowelizacji. Czy się udało? Energia i Recykling: gospodarka obiegu zamkniętego, 4, 10-12.

Lindhqvist, T. (2000, May). Extended Producer Responsibility in Cleaner Production: Policy Principle to Promote Environmental Improvements of Product Systems. Doctoral Dissertation. Lund: IIIEE, Lund University.

MKPL (2020). Ministerstwo Klimatu: Rozszerzona Odpowiedzialność Producenta. Retrieved from: https://www.gov.pl/attachment/1b2f459e-ad9d-4fe7-baef8ec7a110ac8a.

Moskwik, K., Krupa, K., Lachowicz, M., \& Roszkowski, M. (2020, June). Rozszerzona odpowiedzialność producenta w sektorze gospodarki odpadami. Report. Warszawa: Instytut Jagielloński.

NIK (2021, January 8). Działania na rzecz ograniczenia powstawania odpadów z tworzyw sztucznych i ich skutecznego zagospodarowania w Polsce. Informacja o wynikach kontroli: 159/2020/P/19/079/LKR. Retrieved from: https://www.nik. gov.pl/kontrole/P/19/079/.

Ogunmakinde, O.E., Sher, W., \& Egbelakin, T. (2021). Circular Economy Pillars: A SemiSystematic Review. Clean Technologies and Environmental Policy, 23(4), 899-914. DOI: $10.1007 / \mathrm{s} 10098-020-02012-9$.

OJ (2008). Directive 2008/98/EC of the European Parliament and of the Council of 19 November 2008 on Waste and Repealing Certain Directives, OJ L 312 22.11.2008, pp. 3-30.

OJ (2013). Decision No 1386/2013/EU of the European Parliament and of the Council of 20 November 2013 on a General Union Environment Action Programme to 2020 “Living Well, within the Limits of Our Planet", OJ L 354, 28.12.2013, pp. 171-200. 
OJ (2018). Directive (EU) 2018/851 of the European Parliament and of the Council of 30 May 2018 Amending Directive 2008/98/EC on Waste, OJ L 150, 14.6.2018, pp. 109-140.

OJPL (1996). Ustawa z dnia 13 września 1996 r. o utrzymaniu czystości i porządku w gminach, Dz.U. z 2020 r. poz. 1439 [JoL 2020, item 1439].

OJPL (2001). Ustawa z dnia 11 maja 2001 r. o obowiązkach przedsiębiorców w zakresie gospodarowania niektórymi odpadami oraz o opłacie produktowej, Dz.U. z 2020, poz. 1903 [JoL 2020, item 1903].

OJPL (2005). Ustawa z dnia 20 stycznia 2005 r. o recyklingu pojazdów wycofanych z eksploatacji, Dz.U. z 2020 r., poz. 2056 [JoL 2020, item 2056].

OJPL (2009). Ustawa z dnia 24 kwietnia 2009 r. o bateriach i akumulatorach, Dz.U. z 2020, poz. 1850 [JoL 2020, item 1850].

OJPL (2013). Ustawa z dnia 13 czerwca 2013 r. o gospodarce opakowaniami i odpadami opakowaniowymi, Dz.U. z 2020, poz. 1114 [JoL 2020, item 1114].

OJPL (2015). Ustawa z dnia 11 września 2015 r. o zużytym sprzęcie elektrycznym i elektronicznym, Dz.U. z 2020, poz. 1893 [JoL 2020, item 1893].

OJPL (2016). Rozporządzenie Ministra Środowiska z dnia 29 grudnia 2016 r. w sprawie szczegółowego sposobu selektywnego zbierania wybranych frakcji odpadów, Dz.U. z 2019 r., poz. 2028 [JoL 2019, item 2028].

OJPL (2019). Ustawa z dnia 19 lipca 2019 r. o przeciwdziałaniu marnowaniu żywności, Dz.U. z 2020, poz. 1645 [JoL 2020, item 1645].

Pyssa, J. (2015). Rynek elektroodpadów w Polsce. Nowoczesna Gospodarka Odpadami, $8(1-2), 21-24$.

RM (2019). Road Map towards the Transition to Circular Economy. Annex to Resolution No 136/2019 of the Council of Ministers of 10 September 2019. Retrieved from: https://www.gov.pl/web/rozwoj-praca-technologia/gospodarka-o-obieguzamknietym.

ROP (2020, December 16). Rozszerzona odpowiedzialność producentów. Jaki model ROP dla Polski i co z systemem kaucyjnym? Retrieved from: https://portalkomunalny.pl/ rozszerzona-odpowiedzialnosc-producentow-jaki-model-rop-dla-polski-i-co-zsystemem-kaucyjnym-412674/.

Rudewicz, J. (2020). Rola systemów depozytowo-zwrotnych (kaucyjnych) w organizacji recyklingu odpadów komunalnych w państwach Europy. Wykorzystanie automatów RVM (butelkomatów). Prace Komisji Geografii Przemysłu Polskiego Towarzystwa Geograficznego, 34(2), 50-70. DOI: 10.24917/20801653.342.4.

Schroeder, P., Anggraeni, K., \& Weber, U. (2019). The Relevance of Circular Economy Practices to the Sustainable Development Goals. Journal of Industrial Ecology, 23(1), 77-95. DOI: 10.1111/jiec.12732.

Sokołowski, L.M. (2019). The Act on Counteracting Food Waste - An Attempt of Its Evaluation. Przeglad Prawa Rolnego, 25, 167-181. DOI: 10.14746/ppr.2019.25.2.11. Styś, T., \& Foks, R. (2016). Rynek gospodarowania zużytym sprzętem elektrycznym i elektronicznym w Polsce. Perspektywa 2030. Report. Warszawa: Instytut Sobieskiego. 
Styś, T., \& Foks, R. (2016a). System gospodarowania odpadami opakowaniowymi $w$ Polsce. Perspektywa zamknięcia obiegu. Report. Warszawa: Instytut Sobieskiego.

Taranic, I., Behrens, A., \& Topi, C. (2016, July). Understanding the Circular Economy in Europe, from Resource Efficiency to Sharing Platforms: The CEPS Framework. CEPS Special Report, 143. Brussels: Centre for European Policy Studies. Retrieved from: https://www.ceps.eu/wp-content/uploads/2016/07/SR\%20No143\%20Circular\%20 Economy_0.pdf.

Toborek, P. (2021, April 15). Czy rząd obawia się rozszerzonej odpowiedzialności producentów? Retrieved from: https://www.portalsamorzadowy.pl/gospodarka-komunalna/czy-rzad-obawia-sie-rozszerzonej-odpowiedzialnosci-producentow,271822. html.

UC43 (2020). Ustawa o zmianie ustawy o odpadach oraz niektórych innych ustaw Projekt z dnia 13 października 2020 r. Retrieved from: https://legislacja.rcl.gov.pl/ projekt/12339505/katalog/12730155\#12730155.

UC73 (2021). Ustawa o zmianie ustawy o obowiązkach przedsiębiorców w zakresie gospodarowania niektórymi odpadami oraz o opłacie produktowej oraz niektórych innych ustaw - Projekt z dnia 18 marca 2021 r. Retrieved from: https://legislacja. rcl.gov.pl/projekt/12345305/katalog/12777247\#12777247.

UN (2015, October 21). GA Resolution adopted by the General Assembly on 25 September 2015: Transforming Our World: The 2030 Agenda for Sustainable Development, A/RES/70/1. Retrieved from: https://www.un.org/ga/search/view_doc. asp?symbol=A/RES/70/1\&Lang=E.

UNEP (2011). Fischer-Kowalski, M., Swilling, M., von Weizsäcker, E.U., Ren, Y., Moriguchi, Y., Crane, W., Krausmann, F., Eisenmenger, N., Giljum, S., Hennicke, P., Romero Lankao, P., Siriban Manalang, A., Sewerin, S. Decoupling Natural Resource Use and Environmental Impacts from Economic Growth. A Report of the Working Group on Decoupling to the International Resource Panel. United Nations Environment Programme. Retrieved from: https://wedocs.unep.org/handle/20.500.11822/9816 ?show $=$ full.

Victory, M. (2020, August 8). Mixed Market Reaction to EU €800/Tonne Plastics Charge. Recycling Magazine. Retrieved from: https:/www.recycling-magazine. com/2020/08/08/mixed-market-reaction-to-eu-e800-tonne-plastics-charge/. 